\title{
More rows about Europe's money
}

The British government is making a last-minute attempt to persuade the rest of Europe that it has a better way of creating a common currency. It has a good case, but one likely to be overtaken by events - and by the Deutschmark.

If people contemplating marriage prudently anticipate as many of the consequences as they can, why should countries planning union be more casual? Mr John Major, the British Chancellor of the Exchequer, could usefully have used that argument when, last week, he launched his last-ditch campaign against the European Communities' plan to legislate for a single European currency. Major says that the plan now proposed in Brussels is a recipe for enormous intra-European resentment. There is no doubt that he is correct; it is obtuse of national treasurers elsewhere in Europe not to recognize as much. This unsolicited expression of support for Major's isolated position is not biased by the circumstance that his own proposals for the future - the coexistence of national currencies with the European Currency Unit (ECU) - coincides with the interim solution advocated by this journal a year ago (Nature 341,$89 ; 1989$ ).

The correctness of Major's position is well illustrated by the monetary union of the two German states from the beginning of this month. People in the East will now spend a substantial part of their incomes on the products of factories in the West, with the result that many estimates range from 10 per cent to 25 per cent, but reality could be worse - will be thrown out of work. That prospect is palatable only because the special circumstances promise that West German investment in the East will be so substantial and so quick that the economic upheaval will be short-lived. Let us hope so, for the sake of the civility of the united Germany.

The Brussels plan for European monetary union being pushed by the Commission president, M. Jacques Delors, would effect for the whole of the European Commmunities the kind of monetary union East and West Germany agreed last week, but without comparable compensatory arrangements. It is astonishing that the weaker economies in the European Communities, Greece and Ireland, for example, so casually applaud the Delors plan. Major is rightly worrying about Britain's future.

There may yet be a solution. The meeting of the heads of the European Communities' governments last week in Dublin convened not just one, but two, constitutional conferences in December on monetary and political issues respectively. They should be rolled together, for the second could allow the decisions of the first to be made acceptable. The model here is that of the United States, which enjoys the benefits of monetary and politi- cal union within which 50 states retain a substantial degree of autonomy mistaken, in many a state capital, for sovereignty. In practice, the states raise funds from property and sales taxes and take responsibility for education, regional infrastructure and some aspects of welfare, while the federal government uses a nationwide income tax to pay for national defence and supplementary welfare costs. (The costs of federal research agencies such as the National Science Foundation and the National Institutes of Health are peanuts by comparison.)

In Europe, that arrangement is turned upside down. Defence and social security remain national responsibilities, financed by national income taxes, while the nearest thing to a central government (the European Commission) is financed by a sophisticated version of a sales tax, most of which is spent on keeping Europeans working as farmers when they should be doing something else. There is no mechanism by which economic imbalances will be offset by the flow of funds towards the poorer regions. (The European Communities have what is called a social fund, but it is too small to matter and is deliberately marginalized politically.)

Major's proper worry is that monetary union on the basis of fixed exchange rates (the ultimate Delors plan) will rob him and his successors of monetary freedom: interest rates will be determined by the market (and will be lowest in the most productive countries) while the device for repudiating debt called devaluation would be both illegal and impractical. (If West Virginia now sought to solve its economic problems by offering 90 cents for each federal dollar, it would quickly find itself in queer street.)

In the short run, Major is right; let national currencies and the ECU coexist while people get used to the idea, and so that the commercial banks that convert one European currency into another no longer enjoy a right to collect an arbitrary tax on every currency transaction. Further ahead, there can be no monetary union without preceding political union of some kind - at least an understanding of who pays for defence (and thus a common understanding of what defence is for) and a commitment by the rich towards the welfare of the poor. The sad truth about the argument about European monetary union is that there is as yet no serious constituency for either of these causes, and that December is not very far away. 